\title{
GAMBARAN LEARNED HELPLESSNESS WANITA TUNA SUSILA YANG MENGALAMI KEKERASAN
}

\author{
Yulya Indah Sari ${ }^{1}$, Sandi Kartasasmita ${ }^{2}$ \\ ${ }^{1}$ Fakultas Psikologi, Universitas Tarumanagara \\ yulyaindah@gmail.com \\ ${ }^{2}$ Fakultas Psikologi, Universitas Tarumanagara \\ sandik@fpsi.untar.ac.id
}

\begin{abstract}
ABSTRAK
Wanita tuna susila seringkali dihadapkan pada hal-hal yang sulit dan berat untuk dijalani, termasuk label-label tidak menyenangkan yang melekat, perbedaan tingkatan sosial, hingga kekerasan yang didapatkan dari orang-orang sekitar lingkungan. Wanita tuna susila mengaku tidak berdaya apa-apa untuk menolak realitas tersebut. Segala rasa tidak berdaya dan tidak adanya bantuan ini menunjukkan helplessness dari para wanita tuna susila (Price, 1978). Penelitian ini bertujuan memberi gambaran helplessness di balik peranan para wanita tuna susila dalam menghadapi kemalangan dan pengalaman tidak menyenangkan yang dilalui. Penelitian dilakukan dengan menggunakan metode kualitatif, dengan wawancara mendalam terhadap tiga orang wanita yang menjadi wanita tuna susila serta yang mengalami kekerasan namun masih menjalani hidup dalam dunia wanita tuna susila. Hasil penelitian ini menunjukkan bahwa para partisipan mengalami helplessness sebagai dampak kegagalan atas usaha yang dilakukan dan tidak adanya bantuan akibat label negatif wanita tuna susila, menyebabkan tumpulnya motivasi, penurunan kognitif, dan gangguan emosional pada para partisipan.
\end{abstract}

Kata Kunci: learned helplessness, wanita tuna susila, kekerasan

\section{PENDAHULUAN}

\section{Latar Belakang}

Wanita tuna susila merupakan masalah sosial sejak sejarah kehidupan manusia hingga saat ini, di mana wanita tuna susila selalu ada pada setiap tingkat peradaban (Kartono, 2007). Motif para perempuan ini terjun ke dunia wanita tuna susila lebih banyak disebabkan oleh faktor ekonomi, frustrasi, atau adanya persoalan keluarga, namun banyak di antara mereka yang bekerja di tempattempat prostitusi karena dikelabui, dibujuk, dan bahkan karena dipaksa (Syam, 2010). Kehidupan para wanita tuna susila adalah gambaran adanya ketegangan antara apa yang ditampilkan dan apa yang sesungguhnya terjadi. Akan tetapi, sebagian besar orang hanya melihat sesuatu dari tampilan luarnya saja (outward appearance) dan menafikan dimensi terdalam (inward appareance). Oleh karena itu, banyak orang terkecoh dengan kenyataan tersebut (Syam, 2010). Wanita tuna susila seringkali dihadapkan pada hal-hal yang sulit dan berat untuk dijalani dalam kesehariannya (Arivia, 1997). Reaksi sosial terhadap wanita tuna susila dapat bersifat menolak sama sekali dan mengutuk keras, bercampur dengan rasa benci, ngeri, jijik, takut, dan marah (Kartono, 2007). Persepsi yang salah ini menghantarkan para wanita tuna susila ke ambang kerentanan terhadap kekerasan yang meliputi kekerasan fisik, kekerasan verbal, maupun kekerasan seksual (Arivia, 1997).

Sebagian contoh kekerasan yang dialami oleh para wanita tuna susila adalah kekerasan fisik dan verbal yang dialami para wanita tuna susila dari pelanggan selama menggunakan jasa wanita tuna 
susila ataupun dari orang-orang lainnya yang ada disekitar wanita tuna susila (Kartono, 2007). Kekerasan lainnya adalah kekerasan finansial dimana para penjaja seks ini juga hidup dengan diatur dan ditentukan oleh orang lain, orang-orang yang dianggap memiliki peranan penting atas wanita tuna susila tersebut seperti germo atau mammy, orang-orang ini pula yang merasa berhak menerima sebagian besar pemasukan wanita tuna susila (Arivia, 1997). Adapula bentuk perampasan hak untuk tidak diperkerjakan karena adanya label dosa yang melekat seumur hidup para mantan wanita tuna susila itu, ditambah tidak dipercayanya kesusilaan serta tanggung jawab para wanita tuna susila (Kartono, 2007). Posisi penjaja seks ini juga sangat lemah jika terjadi pelecehan yang dilakukan oleh para penguasa setempat atau bahkan polisi (Murray, 1994). Para wanita tuna susila yang menyadari akan keterpinggirannya mengaku tidak berdaya apa-apa untuk menolak realitas tersebut yang muncul dari rasa rendah diri para wanita tuna susila dengan berbagai stereotip yang melekat pada diri masingmasing (Syam, 2010). Perasaan terperangkap oleh stereotip dan stigma negatif dari lingkungan, kecaman lingkungan serta penolakan akan keberadaan para wanita tuna susila yang dialami dalam periode waktu yang panjang tanpa mampu melakukan sesuatu untuk merubah kondisi, memicu tingkat stres yang tinggi dalam diri para wanita tuna susila (Sarafino \& Smith, 2012).

Para wanita tuna susila masih menjalani kehidupan ketunasusilaannya dengan segala keterpaksaan disebabkan oleh rasa ketergantungan finansial. Ketergantungan secara finansial, perasaan tidak memiliki daya, serta keadaan di mana tidak adanya bantuan inilah yang mencerminkan helplessness (Price, 1978). Rasa ketidakberdayaan atas pengalaman berulang yang tidak terkendali yang menurunkan harga diri dan ketidakmampuan melihat peluang usaha untuk mengubah pengalaman berulang yang tidak menyenangkan tersebut yang disebut learned helplessness oleh Martin Seligman (dikutip dalam Hoeksema, 2007). Tujuan penelitian adalah memperoleh gambaran learned helplessness pada wanita tuna susila yang mendapat kekerasan, selain itu, b memberikan info kepada masayarakat untuk lebih memperhatikan bagaimana keadaan yang terjadi pada para wanita tuna susila di balik peran kewanita-tuna-susilaan, serta memberi pengetahuan mengenai learned helplessness guna mencegah rasa ketidakberdayaan.

\section{Learned Helplessness}

Istilah learned helplessness diciptakan berdasarkan penelitian Martin Seligman dengan hewan yang terlihat lelah dan akhirnya mempelajari bahwa hewan tersebut tidak berdaya dalam menghindari kejut yang tidak dapat dihindari. Abramson menjelaskan bahwa helplessness tergantung pada pemikiran bahwa ia tidak mungkin menghadapai masa depan, yang menurut Wortman dan Brehm disebabkan kegagalan dari usaha mengontrol kejadian (dikutip dalam Carver \& Scheier, 1992).

Seligman, Overmier, dan Maier (dikutip dalam Hoeksema, 2007) mengemukakan learned helplessness "when people come to believe they are helpless to control important outcomes in their environment" (h. 321). Learned helplessness terjadi saat individu merasakan bahwa dirinya tidak berdaya untuk mengontrol lingkungannya. Abramson, Peterson, dan Seligman (dikutip dalam Semium, 2006) mengemukakan learned helplessness sebagai "pembelajaran individu secara tepat bahwa ia tidak dapat mengontrol aspek-aspek negatif dari kehidupan; dan dengan demikian, ia merasa tidak berdaya, dan perasaan-perasan ketidakberdayaan ini akan menyebabkan depresi” (h. 424).

Penulis menyimpulkan bahwa learned helplessness adalah keyakinan individu atas ketidakmampuan dirinya dalam menangani, mengontrol, ataupun mengubah keadaan yang terjadi di sekitarnya yang dianggap tidak menyenangkan dan terjadi berulang-ulang, sehingga menimbulkan rasa menyerah dan sikap pasif, disebabkan kegagalan terus-menerus dari usaha yang dilakukan. Dweck dan rekan-rekan menemukan hal penting untuk dicatat berdasarkan hasil eksperimentalnya. Perempuan lebih menunjukkan pola 
helplessness bila dibandingkan dengan laki-laki. Perempuan cenderung lebih menyalahkan kemampuan sendiri untuk kinerja yang buruk ataupun keberhasilan yang rendah, sehingga cenderung menunjukkan kegigihan yang menurun, dan rendahnya harapan akan hasil yang berhasil (dikutip dalam Berk, 1991).

\section{Karakteristik Individu dengan Helplessness}

Seligman (dikutip dalam Halgin \& Whitbourne, 2003) juga menjelaskan, perilaku yang ditunjukkan dari learned helplessness mirip dengan orang yang depresi, individu menunjukkan perilaku ini dalam menanggapi pengalaman sebelumnya dimana individu merasa tidak berdaya untuk mengendalikan nasibnya, yakni sebagai berikut.

Pertama, sulit melihat peluang bantuan (dikutip dalam Price, 1978).Kedua, sikap yang pasif (dikutip dalam Hoeksema, 2007). Ketiga, perilaku rendahnya harapan akan keberhasilan. Individu yang helpless juga memiliki harapan yang rendah akan keberhasilan disebabkan oleh kegagalan yang selama ini dialami secara berulang-ulang, sehingga menyimpulkan bahwa dirinya 'bodoh' maka tidak akan berhasil hingga seterusnya (Papalia et al., 2009).

Keempat, menganggap dirinya tidak memiliki kemampuan (dikutip dalam Berk, 1991). Kelima, berkurangnya usaha individu karena mempelajari bahwa usaha apapun yang dilakukan pada akhirnya akan berujung pada kegagalan, ditambah tidak ada kemampuan maka tidak perlu melakukan usaha apalagi mengulang usaha yang sudah jelas gagal (Berk, 1991). Keenam, ada kecenderungan untuk bunuh diri. Segala kepasifan, percaya bahwa dirinya tidak mampu mengubah kegagalan menimbulkan perilaku kecenderungan bunuh diri bagi para individu yang helpless, karena tidak percaya bahwa akan ada bantuan yang mengeluarkan dirinya dari situasi penuh tekanan Alloy, 1999).

\section{Penyebab Terjadinya Learned Helplessness}

Seligman (dikutip dalam Price, 1978) mengemukakan bahwa Learned Helplessness timbul sebagai reaksi saat individu menemukan bahwa tidak ada jalan untuk menghindari atau menyangkal kejadiankejadian yang dianggap tidak menyenangkan, dan adanya kegagalan dari segala tindakan dan usaha yang dimaksudkan untuk mengubah keadaan yang menekan tersebut. Seligman (dikutip dalam Price, 1978) juga menambahkan bahwa Learned Helplessness semakin berkembang setelah individu mempelajari bahwa dari saat ini individu tidak dapat memperkirakan kejadian yang selanjutnya akan datang disebabkan oleh ketidakmampuan individu mengontrol keadaan sehingga individu merasa semakin tidak berdaya.

Learned helplessness muncul disebabkan oleh rasa tidak berdaya dan rasa terperangkap seseorang yang tidak dapat menghindari hal-hal yang tidak diinginkan (Sarafino \& Smith, 2012). Abramson (dikutip dalam Hoeksema, 2007) berpendapat bahwa rasa putus asa semakin berkembang ketika individu membangun penilaian pesimis bagi diri sendiri dalam menghadapi kejadian dalam hidupnya dan merasa tidak memiliki cara untuk menghadapi peristiwa dalam hidupnya tersebut.

\section{Atribusi Learned Helplessness}

Seligman dan rekan-rekan (dikutip dalam Sarafrino \& Smith, 2012) menerapkan proses kognitif yang disebut atribusi pada revisi teori learned helplessness, di mana ada penilaian tentang 3 dimensi situasi, yakni, pertama, internal-eksternal, yaitu individu menilai apakah ketidakmampuan mengontrol situasi adalah dari dalam diri, ataukah karena sebab eksternal yang bahkan di luar kendali siapapun. Contohnya adalah individu cenderung menyalahkan diri sendiri (Seligman dan rekan, dikutip dalam 
Hoeksema, 2007) dan berpikir dirinya tidak memiliki kemampuan (Seligman, dikutip dalam Slavin, 2009).

Dimensi kedua, stabil-tidak stabil yaitu penilaian apakah keadaan atau situasi ini bersifat tahan lama (stabil), akan terus terjadi, ataukah tidak stabil yaitu bersifat sementara (Sarafrino \& Smith, 2012). Yakni penilaian Penilaian akan situasi yang stabil ini membuat individu merasa bahwa ia akan selalu terjebak, tidak akan pernah berhasil, akan selalu gagal (Slavin, 2009).

Dimensi ketiga, global-spesifik, yaitu penggeneralisasian efek kegagalan yang dialami (global), kegagalan menyeluruh dalam hidup individu (Fausiah \& Widury, 2007), sehingga menurut Seligman (dikutip dalam Sarafino \& Smith, 2012) inidividu akan merasa benar-benar tidak berdaya, Abramson (dikutip dalam Hoeksema, 2007) mengatakan bahwa individu kemudian menilai bahwa peristiwa negatif yang terjadi akan terjadi juga di seluruh bidang kehidupan individu sehingga kegagalan akan terus terjadi di berbagai usaha yang individu lakukan.

\section{Dampak Learned Helplessness}

Seligman (dikutip dalam Lubis, 2009) mengemukakan bahwa learned helplessness mengakibatkan gangguan emosional seperti depresi ringan atau sedang, meningkatkan kecemasan, perasaan tertekan, penurunan motivasi yakni merasa diri tidak memiliki kemampuan, usaha apapun akan berujung kegagalan sehingga memunculkan rasa menyerah (Lubis, 2009), serta penurunan kognitif yaitu gagalnya individu dalam mempelajari respon-respon baru yang dapat membantu individu keluar dari permasalahan atau keadaan yang membuat individu tertekan (Lubis, 2009). Keyakinan individu bahwa dirinya adalah 'bodoh' dan 'tidak mampu' menyebabkan tidak adanya usaha individu untuk mengembangkan kognitif dalam melihat jalan keluar ataupun peluang untuk dapat menangani atau mengontrol keadaan yang terjadi (Papalia, dkk., 2009). hal ini menyebabkan individu yang helpless tidak mengembangkan kognitifnya dalam mencari jalan keluar dari permasalahannya (Slavin, 2009).

\section{Kekerasan}

Geen (dikutip dalam Krahé, 2005) menerangkan istilah kekerasan sebagai salah satu subtipe agresi yang menunjuk pada bentuk-bentuk agresi fisik ekstreem. Kekerasan didefinisikan sebagai pemberian tekanan intensif terhadap orang atau property dengan tujuan merusak, menghukum atau mengkontrol. Archer dan Browne (dikutip dalam Krahé, 2005) mengusulkan definisi kekerasan sebagai serangan fisik yang merusak yang bagaimanapun juga tidak dibenarkan secara sosial. Poewandari (dikutip dalam Jessica \& Roswita, 2007) menjelaskan "kekerasan yaitu tindakan yang disengaja untuk memaksa, menaklukkan, mendominasi, mengendalikan, menguasai, menghancurkan, melalui cara-cara fisik, psikologis, ataupun gabungan-gabungannya dan atau tindakan yang mungkin tidak disengaja, bukan intensional, tetapi didasari oleh ketidaktahuan, kekurangan pedulian, atau alasan-alasan lain yang menyebabkan partisipan secara langsung atau tidak langsung terlibat dalam upaya pemaksaan, menaklukkan, menghancurkan, mendominasi, dan merendahkan orang lain".

Berdasarkan definisi-definisi, maka penulis menyimpulkan bahwa kekerasan adalah perbuatan pemberian tekanan bersifat mengharuskan yang dilakukan baik seseorang maupun kelompok yang menyebabkan kerusakan atau cedera.

\section{Faktor-faktor Penyebab Kekerasan}

Berkowitz (1995) menyatakan bahwa kekalahan korban atau rasa sakit yang ditampilkan oleh korban adalah sesuatu yang menyenangkan bagi pelaku. Korban kekerasan yang dapat mengekspresikan dan 
menampilkan rasa sakit akibat kekerasan yang didapatkannya atau dilakukan oleh pelaku, dapat dikatakan merupakan penguat bagi pelaku untuk melakukan pengulangan kekerasan kembali.

Posisi tidak setara yang dibangun di masyarakat antara laki-laki dan perempuan menyebabkan perempuan berada dalam posisi rentan akan kekerasan. Hal ini menjadi salah satu pendukung bagi perlakuan kekerasan pada perempuan, dan menjadikan perempuan sebagai korban yang tidak dapat dibantah (Krahé, 2005). Keadaan tidak berdaya ini tidak hanya didapatkan karena posisi sebagai perempuan, namun juga karena posisi sebagai wanita tuna susila yang tidak memiliki daya untuk seolah-olah menolak kekerasan, maksudnya adalah wanita tuna susila merupakan seperti satu-satunya pilihan bagi mereka, maka mereka dapat dijadikan sasaran korban kekerasan karena tidak memiliki daya untuk seolah-olah menolak kekerasan yang dilakukan oleh berbagai pihak, baik orang-orang sekitar, maupun laki-laki yang menjadi pelanggannya (Arivia, 1997).

\section{Jenis-jenis Kekerasan}

Salah satu bentuk khusus kekerasan dalam penulisan ini adalah kekerasan struktural yakni kondisi masyarakat yang mewariskan akibat merugikan bagi kelompok sosial tertentu. Kekerasan struktural dianggap sebagai fitur laten dalam sistem sosial yang menimbulkan ketidaksetaraan dan ketidakadilan secara sosial, misalnya melalui pelembagaan hierarki kekuasaan antara laki-laki dan perempuan yang menyebabkan perempuan kebanyakan tidak terlindungi dari paksaan seksual laki-laki (Krahé, 2005). Pertama, kekerasan fisik. Kekerasan fisik secara definisi operasional adalah sebagai tindakan yang dilakukan oleh pelaku terhadap korban dengan cara memukul, menampar, mencekik, menendang, melempar barang ke tubuh, menginjak, melukai dengan tangan kosong atau dengan alat atau senjata, menganiaya, menyiksa, membunuh, serta perbuatan lain yang relevan (Sunarto, 2009).

Kedua, kekerasan verbal. Baron dan Byrne (dikutip dalam Thalib, 2002) menyatakan bahwa kekerasan verbal adalah upaya untuk menyakiti orang lain melalui kata-kata dan bukan perbuatan. Aspek verbal termasuk menolak berbicara, berteriak, menjerit, mengutuk, menghina, mencaci maki, memfitnah, dan menyebar gosip. Kekerasan secara verbal meliputi menolak bicara, berteriak, menjerit, mengutuk, menghina, mencaci maki, memfitnah, dan menyebarkan gosip (Hidayat, 2004).

Ketiga, kekerasan seksual. Definisi kekerasan seksual secara operasional dapat digambarkan sebagai tindakan yang mengarah pada ajakan atau desakan seksual seperti menyentuh, meraba, mencium, dan atau melakukan tindakan-tindakan lain yang tidak dikehendaki korban, memaksa korban menonton produk pornografi, gurauan-gurauan seksual yang tidak dikehendaki korban, ucapan-ucapan yang merendahkan dan melecehkan dengan mengarah pada aspek jenis kelamin atau seks korban, memaksa hubungan seks tanpa persetujuan korban, memaksakan melakukan aktivitas-aktivitas seksual yang tidak disukai, pornografi, kawin paksa (Sunarto, 2009). Menurut Rismiyati (2005), tindakan kekerasan seksual meliputi perkosaan, tindakan cabul, hubungan tak wajar, percobaan perkosaan, pelecehan seksual dan trafficking.

\section{Dampak Kekerasan}

Kekerasan memberi dampak negatif bagi korban, yaitu: (a) ketidakberdayaan, ketika berpikir bahwa tidak dapat melakukan apapun, seseorang akan menjadi tidak berdaya, kemudian akan mengalami kegagalan dalam tiap hal yang dilakukan, hal ini disebut dengan ketidakberdayaan; (b) rasa malu. Chaplin (dikutip dalam Yudiati, 2007) mengemukakan bahwa rasa malu merupakan suatu keadaan emosi dengan ciri khas adanya rasa bersalah, hal yang memalukan dan penghindaran; (c) kesedihan (sadness) dan depresi (depression), kesedihan merupakan perann hati yang emosional yang ditandai 
dengan kepasifan relatif, dengan keluhan dan mengeluarkan air mata; (d) kecemasan; (e) kekaburan identitas, biasanya dialami oleh anak-anak yang beranjak remaja; (f) rasa bersalah (Yudiati, 2007); (g) mendatu (dikutip dalam Jessica \& Roswita, 2007) menyebutkan dampak psikologis yang muncul pada korban kekerasan, antara lain harga diri yang rendah, korban menjadi minder, depresi, stres paska trauma, bunuh diri, penyalahgunaan alkohol dan obat-obatan, kecemasan, merasa malu, terisolasi, dan merasa tertekan.

\section{Wanita Tuna Susila}

Istilah yang artinya sama dengan wanita tuna susila banyak dijumpai di dalam masyarakat, seperti: perempuan jalang, perempuan sundal, lonte, dan penjaja seks (Syam, 2010). Menurut Suwartono (dikutip dalam Hutabarat, 2004) penjaja seks adalah, "perempuan yang melakukan hubungan kelamin dengan seseorang atau beberapa orang laki-laki di luar ikatan perkawinan yang sah dengan maksud mendapatkan kepuasan seksual atau mendapatkan bayaran dan keuntungan materi lainnya". Arti yang serupa juga dikemukakan Rahardjo (dikutip dalam Hutabarat, 2004) yang mendefinisikan wanita tuna susila sebagai "seseorang perempuan yang menyediakan dirinya berhubungan kelamin dengan seorang laki-laki disertai imbalan berupa uang dengan standar tertentu di luar pernikahan resmi".

\section{Alasan Kausal menjadi Wanita Tuna Susila}

Motif para wanita terjun ke dunia kewanita-tuna-susilaan lebih banyak ditemukan atas sebab ekonomi, frustrasi atau permasalahan keluarga, namun banyak juga yang ditemukan bekerja dalam bisnis prostitusi ini karena dikelabui, dibujuk, bahkan melalui proses pemaksaan (Syam, 2010). Hudiono (dikutip dalam Hutabarat, 2004) mengemukakan beberapa faktor yang mendorong perempuan menjadi wanita tuna susila. Secara umum perempuan menjadi wanita tuna susila disebabkan oleh kemiskinan, kebodohan, lapangan pekerjaan yang terbatas, keterampilan yang kurang dimiliki oleh perempuan tersebut, serta urbanisasi yang dianggap jalan keluar bagi daerah yang tidak bisa diandalkan untuk memperoleh nafkah, disamping itu semua, juga ada faktor dari permintaan pada jasa seks yang memang tinggi.

Selain itu, alasan kenapa kewanita-tuna-susilaan tidak semakin berkurang adalah karena para wanita tuna susila merasa tidak ada jalan keluar bagi mereka jika mereka harus berhenti dari kegiatan memperdagangkan tubuhnya tersebut, hal ini terjadi sebab pada umunya masyarakat tidak suka memperkerjakan wanita tuna susila ataupun mantan wanita tuna susila, karena dianggap membawa dosa, kurang bisa dipercaya (Kartono, 2007), sampah masyarakat, kaum terpinggirkan, materialistis, tidak bersedia bekerja keras, dan sulit bersungguh-sungguh (Prastya \& Darma, 2011).

\section{Rumusan Masalah}

Rumusan masalah pada penelitian ini adalah bagaimana gambaran learned helpless pada wanita tuna susila yang mengalami kekerasan?

\section{METODE PENELITIAN}

Penelitian ini dilakukan dengan mendasarkan pada metode kualitatif. Partisipan adalah wanita tuna susila yang diperoleh penulis dengan melakukan pendekatan dan menemui wanita tuna susila untuk meminta kesediaan diwawancara. Setelah diperoleh kesepakatan sesuai etika penelitian antara lain identitas dan informasi partisipan dirahasiakan dan hanya digunakan dalam penelitian, penulis 
mendapatkan 3 orang. Pengumpulan data menggunakan panduan wawancara, dan merekam hasil wawancara. Selanjutnya melakukan analisis data menggunakan proses koding atas naskah wawancara (verbatim).

\section{HASIL DAN PEMBAHASAN}

Berikut adalah gambaran partisipan penelitian, yaitu tiga orang wanita tuna susila dengan nama samaran.

Tabel 1. Data Diri Partisipan

\begin{tabular}{llll}
\hline Data Diri & Partisipan 1 & Partisipan 2 & Partisipan 3 \\
\hline Nama samaran & Mawar & Melati & Lili \\
Usia (tahun) & 33 & 35 & 25 \\
Asal & Sulawesi & Surabaya & Manado \\
Area mangkal & Jakarta Pusat & Jakarta Timur & Jakarta Pusat \\
Pendidikan Terakhir & SD & SMP & SMA \\
Lama menjadi WTS (tahun) & 10 & 15 & 5 \\
Usia pertama menjadi WTS (tahun) & \pm 23 & & \pm 20 \\
Status pernikahan & Cerai & Menikah & \pm 20 \\
Rata-rata pendapatan (Rp)/bulan & $\pm .5 .000 .000-$ & \pm 4.000 .000 & $\pm .4 .500 .000-$ \\
& 6.000 .000 & 5.000 .000 & 5.000 .000 \\
\hline
\end{tabular}

Tabel 2. Tabel Awal Menjadi Wanita Tuna Susila

\begin{tabular}{llll}
\hline & \multicolumn{1}{c}{ Mawar } & \multicolumn{1}{c}{ Melati } & \multicolumn{1}{c}{ Lili } \\
\hline Alasan menjadi & Mengalami penipuan & Dijual oleh suami & Keinginan pribadi \\
wanita tuna & akan diberi pekerjaan & & menambah keuangan \\
susila & di Jakarta & & dalam keluarga \\
& pendidikan rendah & pendidikan rendah & pendidikan rendah \\
\hline
\end{tabular}

\section{Gambaran Kausal Awal menjadi Wanita Tuna Susila}

Partisipan pertama (Mawar) mengaku telah menjadi wanita tuna susila/PSK selama kurang lebih sepuluh tahun tanpa diketahui keluarganya. Awal Mawar menjadi PSK, karena menapat tawaran pekerjaan di Jakarta dari tetangga saat di kampung (Sulawesi). Ketika itu Mawar berusia 23 tahun, dan berbekal pendidikan Sekolah Dasar. Kenyataan pahit dialami Mawar, karena dia dipekerjakan sebagai wanita tuna Susila. Dalam perjalna setahun menjalani pekerjaan tersebut, Mawar menikah dengan laki-laki yang berprofesi sebagai pengemudi. Akhirnya Mawar kembali ke Makasar, untuk menitipkan anaknya pada keluarga. Mawar memiliki tanggungjawab untuk membantu ekonomi keluarga. Mawar memutuskan bekerja kembali sebagai wanita tuna susila, dengan menyamar sebagai penjual minuman. 
Partisipan kedua (Melati) mengaku telah menjalani kehidupan sebagai wanita tuna Susila kurang lebih 15 tahun di bawah pengawasan suaminya tanpa diketahui anggota keluarga Melati. Melati mengaku telah melakukan hubungan seksual pada umur 13 tahun dengan pacarnya. Melati kemudian berganti pacar dan hamil dengan pacar berikutnya yang berujung pada pernikahan atas desakan keluarga. Alasan keuangan yang sangat kurang, Melati secara terpaksa menyetujui rencana suami untuk dijadikan wanita tuna Susila. Pekerjaan sebagai wanita tuna Susila harus dijalani hingga anak kedua lahir. Melati tidak dapat membantah suami karena suami sering memukuli Melati, dan hingga saat ini Melati belum dapat membantah paksaan suami.

Partisipan ketiga (Lili) mengaku telah menjalani kehidupan sebagai PSK selama kurang lebih 5 tahun tanpa diketahui anggota keluarga termasuk suaminya. Alasan Lili menjadi wanita tuna Susila, adalah factor keuangan keluarga, untuk mencukupi kehidupan bersama suami. Lili tidak menceritakan pekerjaan yang sebenarnya pada suami. Lili berbohong pada suaminya dengan mengatakan bahwa Lili telah pindah tempat kerja, walau sama-sama di tempat karaoke namun lebih jauh dan shiftnya menjadi malam hingga pagi.Waktu siang hari digunakan Lili untuk berberes-beres di rumah dan merawat buah hati tercintanya.

\section{Penyebab Mendapat Kekerasan}

Berdasarkan hasil analisis data yang diperoleh, maka dapat ditampilkan penyebab mendapat kekerasan dari para Partisipan penelitian, sebagaimana tercantum dalam tabel 3.

Tabel 3. Tabel Penyebab Mendapat Kekerasan

\begin{tabular}{lccc}
\hline & Mawar & Melati & Lili \\
\hline Ketidaksetaraan dengan pelanggan & $\sqrt{ }$ & $\sqrt{ }$ & $\sqrt{ }$ \\
Ketidakmampuan ekonomi & $\sqrt{ }$ & $\sqrt{ }$ & $\sqrt{ }$ \\
Perasaan tidak berdaya & $\sqrt{ }$ & $\sqrt{ }$ & $\sqrt{ }$ \\
Perasaan lemah & $\sqrt{ }$ & $\sqrt{ }$ & $\sqrt{ }$ \\
Ketidakmampuan komunikasi secara terbuka & $\sqrt{ }$ & $\sqrt{ }$ & $\sqrt{ }$ \\
Ketidakmampuan bersikap & $\sqrt{ }$ & & \\
\hline
\end{tabular}

\section{Kekerasan yang Dialami}

Kekerasan yang dialami oleh para partisipan adalah kekerasan fisik, verbal, dan seksual, sebagaimana tercantum dalam tabel 4.

\begin{tabular}{cccc} 
& \multicolumn{3}{c}{ Tabel 4. Kekerasan yang Dialami } \\
\hline kekerasan & Mawar & Melati & Lili \\
\hline Fisik & $\sqrt{ }$ & $\sqrt{ }$ & $\sqrt{ }$ \\
Verbal & $\sqrt{ }$ & $\sqrt{ }$ & $\sqrt{ }$ \\
Seksual & $\sqrt{ }$ & $\sqrt{ }$ & $\sqrt{ }$ \\
\hline
\end{tabular}

\section{Kekerasan yang Dialami}

Sumber kekerasan yang dialami partisipan bermacam-macam. Sumber kekerasan ini dapat dilihat pada tabel 5. 
Tabel 5. Sumber Kekerasan yang Dialami

\begin{tabular}{|c|c|c|c|}
\hline Kekerasan & Mawar & Melati & Lili \\
\hline Fisik & $\begin{array}{l}\text { - Mengalami dari } \\
\text { tamu atau pelanggan } \\
\text { - penjaga tempat } \\
\text { sebelumnya } \\
\end{array}$ & $\begin{array}{l}\text { - mengalami dari } \\
\text { suami } \\
\text { - tamu atau pelanggan }\end{array}$ & $\begin{array}{l}\text { mengalami dari } \\
\text { tamu atau } \\
\text { pelanggan }\end{array}$ \\
\hline Verbal & $\begin{array}{l}\text { - dari tamu atau } \\
\text { pelanggan } \\
\text { - rekan-rekan sesama } \\
\text { WTS } \\
\text { - orang-orang } \\
\text { lingkungan sekitar } \\
\text { tempat tinggal }\end{array}$ & $\begin{array}{l}\text { - dari suami } \\
\text { - tamu atau pelanggan } \\
\text { - dari rekan-rekan } \\
\text { sesama WTS }\end{array}$ & $\begin{array}{l}\text { - dari tamu atau } \\
\text { pelanggan } \\
\text { - rekan-rekan } \\
\text { sesama WTS } \\
\text { - orang-orang } \\
\text { sekitar tempat } \\
\text { tinggal } \\
\end{array}$ \\
\hline Seksual & $\begin{array}{l}\text { - Trafficking oleh } \\
\text { tempat wanita tuna } \\
\text { susila yang } \\
\text { sebelumnya } \\
\text { - Pemaksaan gaya } \\
\text { seksual oleh tamu } \\
\text { atau pelanggan } \\
\text { - memaksakan } \\
\text { melakukan aktivitas } \\
\text { seksual yang tidak } \\
\text { disukai }\end{array}$ & $\begin{array}{l}\text { - Trafficking oleh } \\
\text { suami } \\
\text { - Memaksakan } \\
\text { hubungan seksual } \\
\text { tanpa disetujui oleh } \\
\text { Melati dari suami } \\
\text { - Pemaksaan gaya } \\
\text { seksual oleh tamu } \\
\text { atau pelanggan }\end{array}$ & $\begin{array}{l}\text { - Pemaksaan gaya } \\
\text { seksual oleh } \\
\text { tamu atau } \\
\text { pelanggan }\end{array}$ \\
\hline
\end{tabular}

Karakteristik Learned Helplessness

Tabel 6 menunjukkan karakteristik Learned Helplessness yang dialami dan terindikasi ada pada masing-masing partisipan penelitian.

Tabel 6. Karakteristik Learned Helplessness

\begin{tabular}{lccc}
\hline & Mawar & Melati & Lili \\
\hline Sulit melihat peluang bantuan & $\sqrt{ }$ & $\sqrt{ }$ & $\sqrt{ }$ \\
Sikap yang pasif & $\sqrt{ }$ & $\sqrt{ }$ & $\sqrt{ }$ \\
Rendahnya harapan akan keberhasilan & $\sqrt{ }$ & $\sqrt{ }$ & $\sqrt{ }$ \\
Menganggap diri tidak memiliki & $\sqrt{ }$ & $\sqrt{ }$ & \\
kemampuan & & $\sqrt{ }$ & $\sqrt{ }$ \\
Berkurangnya usaha & $\sqrt{ }$ & $\sqrt{ }$ & $\sqrt{ }$ \\
Berhenti berusaha & $\sqrt{ }$ & $\sqrt{ }$ & - \\
Kecenderungan untuk bunuh diri & $\sqrt{ }$ & & \\
\hline
\end{tabular}




\section{Atribusi Learned Helplessness}

Gambaran atribusi Learned Helplessness yang dialami oleh para Partisipan penelitian adalah sebagaimana tercantum dalam tabel 7.

Tabel 7. Atribusi Learned Helplessness

\begin{tabular}{lccc}
\hline & Mawar & Melati & Lili \\
\hline Internal - eksternal & Internal & Internal & Eksternal \\
Stabil - tidak stabil & Stabil & Stabil & Stabil \\
Global - spesifik & Global & Global & Global \\
\hline
\end{tabular}

\section{Dampak Learned Helplessness}

Dampak Learned Helplessness yang dialami oleh para partisipan penelitian, dapat dilihat pada tabel 8.

Tabel8. Dampak Learned Helplessness

\begin{tabular}{lccc}
\hline & Mawar & Melati & Lili \\
\hline Gangguan Emosional & $\sqrt{ }$ & $\sqrt{ }$ & $\sqrt{ }$ \\
Penurunan Motivasi & $\sqrt{ }$ & $\sqrt{ }$ & $\sqrt{ }$ \\
Penurunan Kognitif & $\sqrt{ }$ & $\sqrt{ }$ & $\sqrt{ }$ \\
\hline
\end{tabular}

Berdasarkan hasil penelitian, keterlibatan partisipan dalam dunia kewanita-tuna-susilaan karena latar belakang pendidikan dan keterampilan yang tegolong rendah serta paksaan dari orang lain ataupun keadaan ekonomi yang sulit.

Kehidupan menjadi wanita tuna susila berat untuk dijalani karena banyaknya permasalahan yang ditemui, masalah yang cukup berat salah satunya adalah kekerasan yang menimpa para partisipan sebagai wanita tuna susila. Kekerasan fisik yang dialami ketiga partisipan dapat berasal dari pelanggan, ataupun orang-orang disekitar para partisipan, seperti penjaga wanita tuna susila, ataupun suami. Kekerasan lainnya adalah kekerasan verbal, didapatkan dari pelanggan, masyarakat, ataupun rekan-rekan sesama wanita tuna susila. Adapula kekerasan seksual, dari trafficking, atau yang didapat dari pelanggan.

Para partisipan menyadari bahwa usaha masing-masing partisipan hanya mendapatkan kegagalan sebagai hasilnya mulai merasa tidak berdaya dalam menjalani kehidupan sebagai wanita tuna susila yang menemui banyak hal tidak menyenangkan. Posisi partisipan sebagai wanita tuna susila yang merupakan sosok rendah dan hina turut menambah sulitnya keadaan para partisipan. Segala label negatif dan penolakan pada ketiga partisipan menyebabkan tidak adanya bantuan bagi ketiga partisipan dan justru menambah beban penderitaan dan hambatan.

Usaha-usaha yang dirasa sia-sia karena terus menerus mendatangkan kegagalan sebagai hasilnya memberikan keyakinan pada para partisipan bahwa masing-masing diri tidak memiliki kemampuan untuk melakukan sesuatu dalam mengubah situasi tidak menyenangkan. Keyakinan tidak berdaya ini semakin mengurangi motivasi para partisipan untuk mencari jalan keluar, hingga akhirnya ketiga partisipan berhenti dalam mencari dan melakukan usaha untuk menghindari, mengubah, menghentikan atau mengontrol keadaan dan kejadian-kejadian dalam perjalanan kehidupan wanita tuna susila masing-masing partisipan. Perilaku-perilaku inilah yang menunjukkan adanya karakteristik Learned Helplessness pada ketiga partisipan. Para partisipan sulit melihat adanya 
peluang bantuan bagi masing-masing, berkurangnya usaha dan bahkan berhenti berusaha karena rendahnya harapan keberhasilan.

\section{KESIMPULAN DAN SARAN Kesimpulan}

Hasil penelitian menunjukkan bahwa para partisipan berasal dari keluarga dengan tingkat ekonomi rendah, latar belakang pendidikan dan keterampilan juga rendah, sehingga menjadi suatu kesulitan bagi para subyek untuk keluar dari kehidupan wanita tuna susila dan mencari nafkah dengan cara yang berbeda. Para partisipan mengalami learned helplessness sebagai dampak kegagalan atas usaha yang dilakukan dan tidak adanya bantuan akibat label negatif wanita tuna susila, menyebabkan tumpulnya motivasi, penurunan kognitif, dan gangguan emosional pada para partisipan.

\section{Saran}

Saran untuk penelitian selanjutnya yaitu penelitian dengan metode kualitatif yang mewajibkan wawancara sebagai sumber pencarian data. Disarankan untuk dapat memperkecil jarak antara peneliti dan partisipan atau dapat lebih mengakrabkan diri pada partisipan sehingga partisipan dapat semakin terbuka dalam cerita secara lugas. Disarankan juga untuk dapat mewawancarai orang-orang terdekat partisipan sehingga data tidak hanya berpusat pada partisipan saja, maka data akan lebih variatif dan makin lengkap demi kepentingan analisis.

Saran bagi Pemerintah diharapkan untuk dapat memikirkan mengenai pendidikan yang saat ini kurang menjangkau ke kehidupan rakyat kecil atau kurang mampu. Pemerintah juga diharapkan dapat memperluas lapangan pekerjaan dan memilkirkan cara yang yang baik serta tegas untuk mengurangi atau menghambat pertumbuhan penjualan manusia seperti ini agar tidak semakin menjamur luas.

Saran bagi Masyarakat diharapkan untuk tidak sembarang memberi penilaian, namun membantu para PSK untuk tidak melanjutkan pekerjaannya saat ini dan pindah haluan ke pekerjaan lainnya serta untuk dapat menerima masa lalu para wanita tuna susila yang telah berhenti dan tidak membedabedakan berdasarkan masa lalunya, sehingga kisah seperti Mawar tidak terulang kembali.

Saran bagi para wanita tuna susila ataupun mantan wanita tuna susila dengan adanya hasil penelitian yang menunjukkan bahwa kerasnya dunia penjajakan seksual ini yang erat dengan kekerasan, pergunjingan, ataupun pengucilan, yang jelas menunjukkan bahwa pekerjaan bidang seksual ini sungguh merugikan bagi pihak para wanita tuna susila sendiri serta meresahkan masyarakat mengharapkan kepada para wanita tuna susila untuk dapat memikirkan kembali kelanjutan pekerjaan di bidang ini, ada baiknya bila mulai berpindah arah ke pekerjaan lain. Berpindahnya ke pekerjaan lain dapat ditunjang dengan mengikuti pengayaan kemampuan seperti kursus untuk meningkatkan level individu di dunia kerja.

\section{Ucapan Terima Kasih}

Terima kasih kepada para partisipan penelitian yang bersedia diwawancara. Juga terimakasih kepada pihak Universitas Tarumanagara yang sangat berperan dalam penyelesaian penelitian ini.

\section{REFERENSI}

Alloy, L. B., Jacobson, N. S., \& Acocella, J. (1999). Abnormal psychology: Current perspectives. $\left(8^{\text {th }}\right.$ ed.). New York, NY: McGraw Hill. 
Apollo. (2005). Sikap orang tua terhadap anak perempuan di komunitas utama penghasil pelacur. Jurnal Ilmiah Psikologi MANASA. Vol. 1. April. 1-5.

Arivia, G. (1997). Prostitusi berkah atau kutukan. Jurnal Perempuan, 2, Desember/Januari, 3-7, 19.

Berk, L. E. (1991). Child development. Boston: Allyn and Bacon.

Berkowitz, L. (1995). Agresi: Sebab dan akibat. (H. W. Susiatni, Penerj.). Jakarta: Pustaka Binarman Pressindo.

Carver, C. S., \& Scheier, M. F. (1992). Perspectives on personality (2 ${ }^{\text {nd }}$ ed.). Boston: Allyn and Bacon.

Fausiah, F., \& Widuri, J. (2007). Psikologi abnormal klinis dewasa. Jakarta: Universitas Indonesia.

Halgin, R. P., \& Whitbourne, S. K. (2003). Abnormal psychology: Clinical perspectives on psychological disorders. ( $4^{\text {th }}$ ed.). New York, NY: McGraw Hill.

Hall, C. S., \& Lindzey, G. (1993). Psikologi kepribadian 3: Teori-teori sifat dan behavioristic. Yogyakarta: Kanisius.

Hidayana, I. M. (2004). Seksualitas: Teori dan realitas. Jakarta: Program Gender \& Seksualitas FISIP UI.

Hidayat, S. (2004). Hubungan perilaku kekerasan fisik ibu pada anaknya terhadap munculnya perilaku agresif pada anak SMP. Jurnal Provitae. Vol 1. Desember. 81-86.

Hoeksema, S. N. (2007). Abnormal psychology. (4 ${ }^{\text {th }}$ ed.). New York: McGraw Hill.

Hull, T. H., Sulistyaningsih, E., \& Jones, G. W. (1997). Pelacuran di Indonesia: Sejarah dan perkembangannya. Jakarta: Pustaka Sinar Harapan.

Hutabarat, D. B. (2004). Penyesuaian diri perempuan pekerja seks dalam kehidupan sehari-hari. Jurnal Ilmiah Psikologi ARKHE, 9 (2), h. 70-71.

Jessica, M., \& Roswita, Y. (2007). Dampak psikologis pada dewasa muda korban kekerasan dalam berpacaran. Jurnal Kajian Ilmiah PSIKODIMENSIA, 6 (2). Juli-Desember, h.167-174.

Kartono, K. (2007). Patologi sosial. Jakarta: Raja Grafindo Persona.

Krahé, B. (2005). Perilaku agresif. (H. P. Soetjipto \& M. Soetjipto, Penerj.). Jakarta: Pustaka Pelajar Offset.

Lestari, R., \& Koentjoro. (2002). Pelatihan berpikir optimis untuk meningkatkan harga diri pelacur yang tinggal di panti dan luar panti sosial. Jurnal Ilmiah Berskala Psikologi INDIGENOUS, 6 (2), 134-146.

Lubis, N. L. (2009). Depresi tinjauan psikologis. Jakarta: Kencana.

Murray, A. J. (1994). Pedagang jalanan dan pelacuran Jakarta: Sebuah kajian antropologi sosial. (N. Majidi, Penerj.). Jakarta: Pustaka LP3ES Indonesia.

Papalia, D. E., Feldman, R., \& Olds, S. (2009). Human development (11 $1^{\text {th }}$ ed.). New York: McGraw Hill.

Prastya, C., \& Darma, A. (2011). Dolly: Kisah pilu yang terlewatkan. Yogyakarta: Pustaka Pena.

Price, R. H. (1978). Abnormal behavior: Perspectives in conflict. New York: Holt, Rinehart and Winston.

Rismiyati, E. K. (2005). Kekerasan terhadap perempuan, suatu renungan. Jurnal Psikologi. Vol. 15. Maret. 95-97. 1.

Sarafino, E. P., \& Smith, T. W. (2012). Health psychology: Biopsychology interactions $\left(7^{\text {th }}\right.$ ed.). New Jersey: John Wiley \& Sons.

Seligman, M. (1975). Learned Helplessness. G. Reyes., J. D. Elhai., \& J. D. Ford (ed). The encyclopedia of psychological trauma (hal. 381-382). New Jersey: John Wiley \& Sons.

Slavin, R. E. (2009). Educational psychology: Theory and practice. New Jersey: Pearson Education. Sunarto. (2009). Televisi, kekerasan, dan perempuan. Jakarta: Kompas Media Nusantara. 
Syam, N. (2010). Agama pelacur: Dramatugi transendental. Yogyakarta: LKiS.

Thalib, S. B. (2002). Dinamika sosial psikologis perilaku kekerasan siswa Jurnal Ilmiah Psikologi ARKHE, 7 (2) September, 81-82.

Yudiati, E. A. (2007). Studi eksploratif mengenai dampak psikologis akibat kekerasan yang diterima anak dalam keluarga. Jurnal Kajian Ilmiah PSIKODIMENSIA 6 (1) Januari-Juni, 75-82. 